\title{
HUBUNGAN DEPRESI MATERNAL DENGAN FUNGSI KOGNISI ANAK USIA 7 - 14 TAHUN
}

\section{The Association between Maternal Depression and Cognitive Function of Children Age 7 - 14 Years}

Ika Saptarini", Anissa Rizkianti, Prisca Petty Arfines, Suparmi

Badan Penelitian dan Pengembangan Kesehatan, Kementerian Kesehatan RI Jl. Percetakan Negara No. 29 Jakarta Pusat, Indonesia

*E-mail: dr.ikasaptarini@gmail.com

Naskah masuk 15 September 2019; review 29 Mei 2020; disetujui terbit 26 Juni 2020

\begin{abstract}
Background: Investing in early childhood growth and development is a strategy for preparing a better future generation. Ensuring maternal mental health, including maternal depression, is a significant effort to achieve responsive care.

Objective: This study aims to analyse the association between maternal depression and cognitive function of children aged 7 - 14 years at two points, in 2007/2008 and 2014/2015.

Methods: This study used IFLS-4 and IFLS-5 data. The unit of analysis were children aged 7 - 14 years and mothers who lived in the same household. Children's cognitive function was measured using the Raven method, while maternal depression was measured using CESD-10. The analysis was performed using linear regression.

Results: From the IFLS-4 data, there was a significant association between maternal depression and cognitive function of children aged $7-14$ years. Children aged $7-14$ years with mothers with depression have a risk of having cognitive function 0.1 lower which measure with Z-score (SE: 0.05) than children with mothers without depression. However, in IFLS-5, there was no significant association between maternal depression and cognitive function.

Conclusion: There were different results regarding the association between maternal depression and cognitive function of children aged $7-14$ at the two points observed. Further studies need to be done to analyse the causality between maternal depression and cognitive function in children.
\end{abstract}

Keywords: cognitive function, maternal depression. CESD-10, the raven test

\begin{abstract}
Abstrak
Latar belakang: Investasi pada tumbuh kembang anak usia dini merupakan strategi menyiapkan generasi penerus bangsa yang lebih baik. Menjaga kesehatan mental ibu termasuk depresi maternal merupakan upaya untuk mencapai pengasuhan yang responsif.

Tujuan: Studi ini bertujuan untuk melihat hubungan antara depresi maternal dengan fungsi kognisi anak usia 7 14 tahun pada dua titik yaitu tahun 2007/2008 dan tahun 2014/2015.

Metode: Studi ini menggunakan data IFLS-4 dan IFLS-5. Unit analisis adalah anak usia 7 - 14 tahun dan ibu yang tinggal dalam satu rumah. Kognisi anak diukur menggunakan metode Raven, sedangkan depresi maternal diukur menggunakan CESD-10. Analisis dilakukan menggunakan regresi linear.

Hasil: Dari data IFLS-4 didapatkan hubungan yang bermakna antara depresi maternal dan fungsi kognisi anak usia $7-14$ tahun. Anak usia 7 - 14 tahun dengan ibu mengalami depresi berisiko memiliki fungsi kognisi 0,1 lebih rendah yang dinilai menggunakan Z-score (SE:0,05) dibanding anak dengan ibu tanpa depresi. Namun pada IFLS-5 tidak terdapat hubungan yang bermakna antara depresi maternal dan fungsi kognisi.

Kesimpulan: Terdapat hasil yang berbeda terkait hubungan depresi maternal dan fungsi kognisi anak usia $7-14$ tahun pada dua titik tahun yang diamati. Perlu dilakukan studi lanjutan untuk melihat kausalitas antara depresi maternal dan fungsi kognisi anak.
\end{abstract}

Kata kunci: fungsi kognisi, depresi maternal, CESD-10, tes raven 


\section{PENDAHULUAN}

Investasi pada tumbuh kembang anak usia dini merupakan strategi menyiapkan generasi penerus bangsa yang lebih baik. Kualitas anak saat ini akan menjadi modal utama bagi pembangunan bangsa di masa yang akan datang. Investasi ini mencakup pendidikan, sosial, budaya serta perilaku yang membantu menciptakan dukungan awal kehidupan dan memberikan bekal kemampuan pada saat anakanak tumbuh dewasa. ${ }^{1}$ Perhatian masyarakat akan berpengaruh pada kesehatan, pengasuhan serta kesejahteraan anak-anak terhadap kesiapan sekolah, prestasi akademik serta partisipasi angkatan kerja semakin meningkat. ${ }^{2}$ Salah satu aspek penting dari perkembangan adalah fungsi kognisi. Fungsi kognisi yang lebih baik dikaitkan dengan prestasi akademik serta kesehatan mental dan fisik yang lebih baik. Dalam hal ekonomi, fungsi kognisi yang lebih baik juga berhubungan dengan pekerjaan dan pendapatan yang lebih baik dan pada akhirnya berdampak pada pertumbuhan ekonomi negara. Perkembangan kognisi anak dipengaruhi oleh faktor genetik, biologis, sosial, dan psikologis. Secara lebih luas perkembangan kognisi anak juga dipengaruhi oleh kemiskinan, norma budaya, dan lingkungan termasuk pengasuhan anak. ${ }^{3}$

Masalah tumbuh kembang anak termasuk fungsi kognisi juga masih menjadi perhatian dunia terutama di negara berkembang. ${ }^{4}$ Berdasarkan data Badan Pusat Statistik Indonesia tahun 2018, kualitas sumber daya manusia di Indonesia tergolong rendah. Penduduk berusia 15 tahun ke atas yang bekerja didominasi oleh tamatan SD sebanyak 25 persen dan diikuti oleh tamatan SLTP sebanyak 18 persen. Artinya, masih banyak pekerja Indonesia yang berusia 15 tahun ke atas yang memiliki tingkat pendidikan rendah. Rendahnya kualitas pekerja Indonesia juga terkait investasi rumah tangga pada pendidikan anak. ${ }^{5}$ Investasi orang tua terhadap anak-anak mereka, bergantung pada sumber daya rumah tangga yang dapat digunakan dan dialihkan kepada anak-anak mereka termasuk kondisi

*Korespondensi:

(dr.ikasaptarini@gmail.com)

(C) Badan Penelitian dan Pengembangan Kesehatan

ISSN: 2354-8762 (elektronik); ISSN: 2087-703X (cetak) orang tua itu sendiri. Ibu mengambil peran penting sebagai pengasuh utama keluarga, baik untuk mengatur produksi rumah tangga serta pengasuhan anak termasuk merangsang perkembangan fungsi kognisi pada anak. Ibu juga memengaruhi interaksi sosial bayi dan membantu anak dalam mengenal lingkungan atau dunia luar. Kehangatan dan keterikatan emosional ibu dan anak berhubungan dengan kemampuan kognisi dan sosial-emosional pada anak. $^{3}$ Menjaga kesehatan baik fisik maupun mental ibu sangat penting untuk menghasilkan generesi penerus bangsa yang unggul. Namun, peran pengasuhan ibu terhadap anak mulai bergeser. Peran ibu mulai digantikan oleh pengasuh atau keluarga seperti ayah, kakek, nenek, atau kerabat. Hal ini salah satunya disebabkan oleh semakin banyaknya perempuan yang masuk ke angkatan kerja. Tingkat Partisipasi Angkatan Kerja (TPAK) perempuan menurut Survei Angkatan Kerja Nasional (Sakernas) pada tahun 2007 sebesar 49,5 persen yang meningkat menjadi 50,4 persen pada tahun 2014 dan mencapai 55,5 persen pada tahun $2019 .^{6-8}$

Depresi merupakan gangguan mental yang lebih umum terjadi pada perempuan dibanding laki-laki. Sebelum masa pubertas, prevalensi depresi di dunia masih rendah dan prevalensi depresi pada laki-laki lebih tinggi dibanding perempuan. Namun setelah pubertas, prevalensi depresi pada perempuan meningkat dua hingga tiga kali lipat dibanding laki-laki dan prevalensi ini tetap stabil sampai usia dewasa. Hal ini terjadi karena pada masa pubertas, perempuan lebih rentan mengalami dampak perubahan hormonal pada masa transisi pubertas. Hormon reproduksi perempuan termasuk estrogen dan progesteron memodulasi berbagai sistem neurotransmitter di otak, termasuk sistem serotonergik, dopaminergik, dan GABAergic. Aktivasi hormon reproduksi dimulai selama masa pubertas. Hal ini juga akan memengaruhi kepekaan terhadap lingkungan dan dapat berdampak pada psikologi. Lebih lanjut, pada 
masa kehamilan terjadi perubahan dalam sistem neurohormonal. Hormon reproduksi seperti estrogen, progesteron, beta-endorphin dan human chorionic gonadotrophin (hCG) meningkat selama kehamilan. Namun begitu bayi lahir, hormon-hormon ini akan turun secara drastis. Estrogen dan progesteron tidak hanya berperan dalam fungsi reproduksi perempuan, namun juga terlibat dalam pengaturan mood dan fungsi mental yang lebih baik. Penurunan hormon estrogen dan progesteron setelah melahirkan secara drastis dapat menjadi pemicu awal terjadinya gangguan mood pada ibu. ${ }^{9,10}$ Selain itu, depresi pada ibu (depresi maternal) diketahui dapat memengaruhi perilaku pengasuhan yang diberikan ibu pada anaknya, yang kemudian memberikan pengaruh negatif bagi tumbuh kembang anak. Anak dari orang tua yang mengalami depresi berisiko mengalami perlekatan yang tidak nyaman dan aman (insecure attachment), kemampuan kognisi rendah, gangguan perilaku dan interpersonal. ${ }^{11,12}$ Depresi maternal meningkatkan kemungkinan perilaku pengasuhan yang negatif termasuk ketidaksabaran, sensitivitas yang rendah, dan perilaku emosional sehingga menyebabkan interaksi negatif ibu-anak. Namun hasil yang berbeda-beda ditemukan terkait hubungan antara depresi maternal dan kemampuan kognisi anak. Beberapa penelitian menunjukkan bahwa anak dari ibu yang mengalami depresi kronis memiliki kemungkinan lebih besar untuk memiliki perkembangan kognisi yang lebih buruk. ${ }^{13,14}$ Sebaliknya penelitian kohor yang dilakukan oleh Ibanez di Perancis menyimpulkan bahwa depresi maternal tidak memiliki pengaruh yang tidak bermakna terhadap perkembangan kognitif anak. ${ }^{15}$ Demikian pula Hanley et al. melaporkan bahwa tidak terdapat perbedaan bermakna antara anak dengan ibu yang mengalami depresi sebelum dan sesudah melahirkan yang diamati menggunakan Bayley Scales of Infant Development edisi ketiga (BSID-III). ${ }^{16}$ Studi ini bertujuan melihat hubungan antara depresi maternal dengan fungsi kognisi anak usia $7-14$ tahun pada dua titik yaitu tahun 2007/2008 dan tahun 2014/2015.

\section{METODE}

Penelitian ini menggunakan data Indonesia Family Life Survey gelombang empat (IFLS-4) dan gelombang lima (IFLS-5). Indonesia Family Life Survey merupakan survei dengan skala besar yang mewakili sekitar 83 persen dari seluruh populasi Indonesia. Indonesia Family Life Survey mengumpulkan informasi di tingkat individu dan rumah tangga, termasuk karakteristik demografi, sosial ekonomi dan kesehatan.. ${ }^{17}$ Indonesia Family Life Survey gelombang 4 dan 5 juga mengumpulkan informasi mengenai gejala depresi yang diukur pada responden berusia 15 tahun ke atas yang pada gelombang sebelumnya tidak dikumpulkan. Selain itu, IFLS juga mengumpulkan data mengenai pengukuran kognisi pada anak dan dewasa. Pengukuran kognisi menggunakan dua instrumen yang berbeda. Pertama untuk anak usia 7 - 14 tahun dan kedua untuk dewasa usia 15 tahun ke atas. Penelitian ini membatasi unit analisis pada anak usia 7 - 14 tahun baik pada IFLS-4 maupun IFLS-5 sehingga responden yang terpilih pada IFLS-4 akan berbeda dengan reponden pada IFLS-5. Pemilihan sampel ini juga bertujuan untuk menghindari adanya bias pengukuran. Selain itu, pada usia ini anak masih dalam usia wajib belajar sekolah dasar dan sekolah menengah pertama. Pada usia ini kognisi anak berkembang secara progresif karena adanya pembelajaran hal-hal yang baru. ${ }^{18}$ Alasan lain penggunaan IFLS gelombang 4 dan 5 adalah melihat apakah terdapat perbedaan hubungan depresi maternal dan fungsi kognisi anak usia 7 - 14 tahun pada dua titik tahun yang diamati. Kriteria inklusi pada penelitian ini adalah anak berusia 7 - 14 tahun tinggal dalam satu rumah bersama ibu kandung serta memiliki informasi lengkap tentang gejala depresi dan pengukuran fungsi kognisi pada anak. Pada IFLS-4 sebanyak 6.400 anak usia $7-14$ tahun dan pada IFLS-5 terdapat 7.764 anak. Setelah dilakukan data cleaning maka didapatkan jumlah sampel sebesar 4.463 responden pada IFLS-4 dan 4.997 pada tahun IFLS-5 


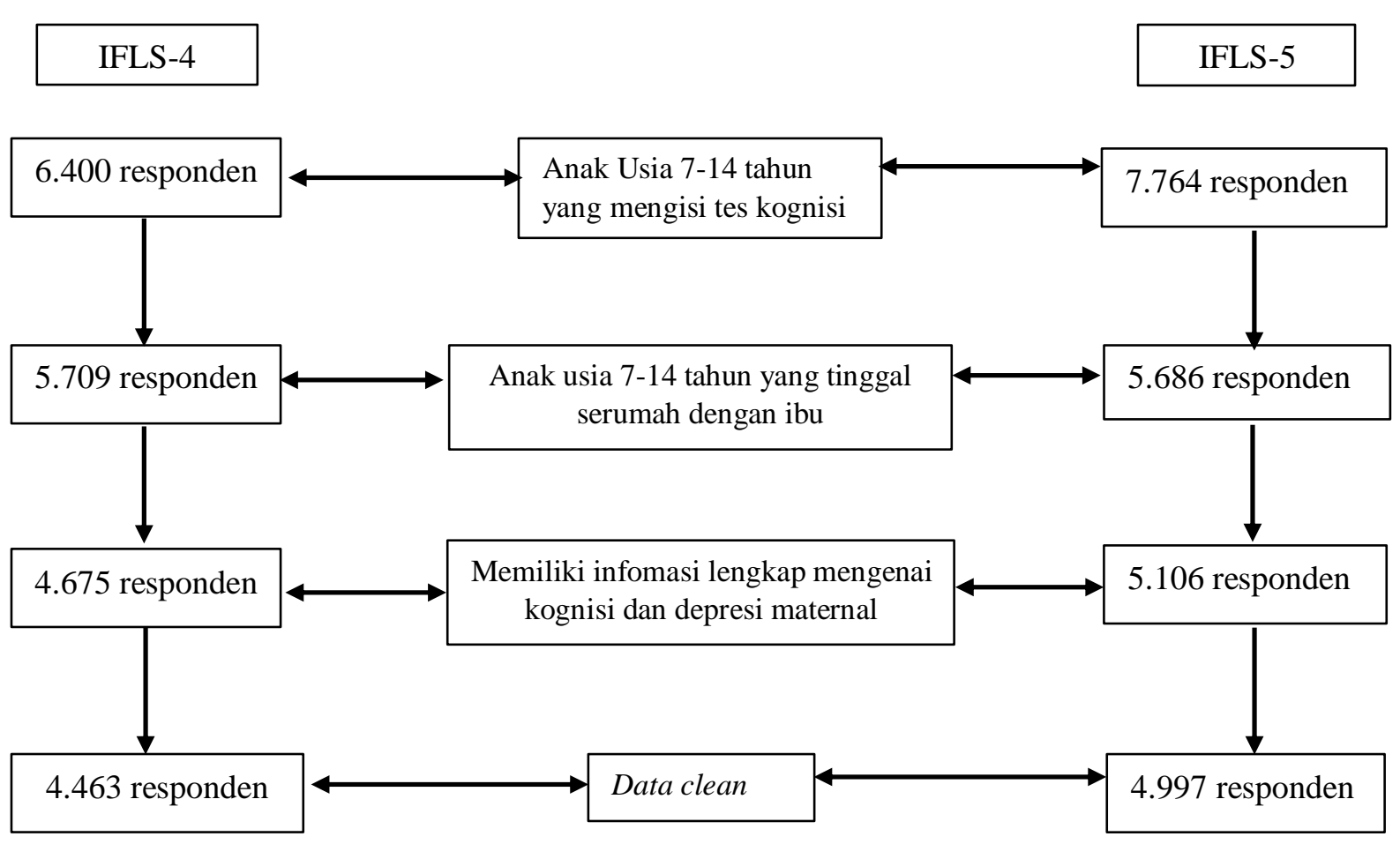

Gambar 1. Bagan Pemilihan Sampel Penelitian

Kemampuan kognisi merupakan kemampuan seseorang dalam menanggapi, memproses, menyimpan, berpikir, dan menggunakan informasi untuk menanggapi suatu tugas atau berbagai jenis situasi lingkungan sesuai umur. Indonesia Family Life Survey mengumpulkan data mengenai kognisi anak berumur $7-14$ tahun menggunakan tes Raven's Progressive Matrices. Di dalam IFLS pengumpulan data dilakukan dengan berbagai kuesioner yang terbagi ke dalam berbagai buku yang biasanya ditujukan dengan peruntukan responden yang berbeda. Sedangkan pengukuran kognisi dapat ditemukan pada buku cognitive assessment atau disebut buku EK. Terdapat dua jenis pertanyaan dalam IFLS-4 dan IFLS-5 untuk mengukur kognisi yaitu 12 pertanyaan mengenai matriks warna dan lima pertanyaan mengenai matematika. Setiap jawaban benar diberi kode satu (1) dan nol (0) jika salah. Penjumlahan sederhana dilakukan untuk menilai kemampuan kognisi. Namun karena total score meningkat seiring dengan umur anak dan memiliki distribusi kemiringan negatif (negative skewness) maka total score kognisi kemudian diubah menjadi $z$-score untuk menstandarisasi variabel kognisi (standardized cognitive score) dan merupakan variabel kontinu. Variabel $z-$ score nilai kognisi dibuat berdasar rata-rata nilai kognisi dan standar deviasi pada masingmasing titik tahun yang diamati. ${ }^{19}$

Indonesia Family Life Survey juga mengumpulkan informasi mengenai gejala depresi yang diukur menggunakan instrumen Center for Epidemiological Studies Depression dengan sepuluh pertanyaan (CESD-10). Pertanyaan mengenai gejala depresi ini diperoleh di buku 3B dan ditanyakan kepada anggota keluarga berumur 15 tahun ke atas. Instrumen CESD-10 terdiri dari sepuluh pertanyaan mengenai gejala depresi, somatis, dan afeksi positif 7 (tujuh) hari terakhir sebelum survei. Pertanyaan dalam CESD-10 terbagi menjadi tiga kelompok yaitu kelompok pertanyaan mood depresi (pertanyaan $\mathrm{C}, \mathrm{F}$, dan $\mathrm{J}$ ), kelompok pertanyaan mengenai afeksi positif (pertanyaan $\mathrm{E}$ dan $\mathrm{H}$ ) serta pertanyaan mengenai gejala somatis (pertanyaan A, B, D, $\mathrm{G}$, dan I). Instrumen CESD-10 memiliki empat respon yang bernilai antara 0 (gejala kurang dari sehari), 1 ( $1-2$ hari), 2 ( $3-4$ hari) dan 3 (5 - 7 hari) yang mengukur gejala depresi selama seminggu terakhir. Score gejala yang menunjukkan afeksi positif memiliki nilai terbalik. Untuk keperluan penelitian epidemiologi, penjumlahan total sederhana direkomendasikan untuk mengukur tingkat gejala depresi. Andresen et al. (1994) merekomendasikan cut-off 10 untuk skrining 
ada tidaknya depresi. Instrumen CESD-10 juga memiliki reliabilitas yang kuat, sensitivitas dan spesifisitas yang sangat baik dalam skrining untuk depresi pada orang dewasa..$^{20,21}$ Namun demikian, CESD-10 memiliki beberapa kelemahan yang harus diperhatikan. Instrumen CESD-10 juga bukan merupakan instrumen diagnosis depresi. Pada beberapa kelompok CESD-10 juga tidak bisa menggambarkan tingkat keparahan depresi. Oleh karena itu penggunaan cut-off dianjurkan untuk skrining gejala depresi. ${ }^{22}$

Penelitian ini juga menggunakan beberapa variabel kontrol untuk melihat hubungan depresi maternal terhadap fungsi kognisi pada anak usia $7-14$ tahun. Variabel kontrol tersebut meliputi tipe daerah, usia ibu saat melahirkan, pendidikan ibu, status pekerjaan ibu, status ekonomi, sanitasi, tinggi ibu, urutan anak, jenis kelamin anak, kesehatan anak, dan usia anak. Pendidikan dibagi menjadi tiga kategori yaitu rendah (tamat SD ke bawah), menengah (SMP), tinggi (SMA ke atas). Penyusunan variabel status ekonomi didasarkan atas pengeluaran rumah tangga dan dibagi menjadi lima kelompok dari terbawah sampai dengan teratas. Variabel sanitasi menggunakan data penggunaan jamban rumah tangga. Sanitasi dikategorikan layak jika memiliki jamban sendiri dengan septic tank. Beberapa penelitian sebelumnya menyebutkan bahwa terdapat hubungan antara sanitasi dan kognisi pada anak. Mekanisme hubungan ini terjadi melalui penurunan tingkat kesakitan anak yang tinggal di rumah tangga dengan sanitasi yang baik. Meskipun terkadang infeksi bersifat asimptomatis, namun jika hal ini terjadi berulang akan berpengaruh terhadap perkembangan dan kognisi anak. ${ }^{23-25}$ Analisis data IFLS periode 2000 - 2007 juga menunjukkan hasil yang serupa di mana penggunaan sanitasi yang baik dalam rumah tangga berkontribusi sebesar 25 persen terhadap penurunan ketidaksetaraan fungsi kognitif anak. Dalam periode 7 tahun tersebut terdapat 45 persen penurunan ketidaksetaraan fungsi kognitif di Indonesia. ${ }^{26}$ Variabel tinggi badan ibu dikategorikan pendek jika ibu memiliki tinggi kurang dari 150,1 cm. Sedangkan variabel kesehatan anak diukur menggunakan self-rate health (SRH) berdasarkan pengakuan ibu.

Pengolahan data dilakukan menggunakan bantuan piranti lunak Stata 15.1 SE. Data dianalisis menggunakan dua metode yaitu analisis deskriptif dan analisis inferensial. Analisis deskriptif dilakukan untuk mengetahui gambaran umum variabel-variabel yang digunakan dalam penelitian ini. Analisis inferensial dilakukan untuk mengetahui hubungan depresi maternal dengan fungsi kognisi pada pada dua titik yang diamati. Penelitian ini menganalisis pada dua titik berbeda dengan responden yang berbeda dengan tujuan untuk mengetahuai apakah terdapat perubahan hubungan depresi maternal dengan fungsi kognisi anak usia 7 - 14 tahun. Analisis inferensial menggunakan metode regresi linear karena variabel dependen merupakan data kontinu. Variabel dengan nilai $\mathrm{p}<0,05$ dianggap memiliki hubungan bermakna secara statistik.

\section{HASIL}

Total responden penelitian ini adalah 4.463 pada IFLS-4 dan 4.997 pada IFLS-5. Rata-rata usia anak baik pada IFLS-4 maupun IFLS-5 adalah 10,3 tahun. Sedangkan rata-rata umur ibu saat melahirkan pada IFLS-4 adalah 26,3 tahun dan meningkat pada IFLS-5 menjadi 27 tahun. Terjadi peningkatan pendidikan ibu dari tahun 2007/2008 ke 2014/2015. Menurut data IFLS-4 terdapat 26,5 persen ibu dengan anak usia 7 - 14 tahun yang memiliki pendidikan tinggi. Hal ini meningkat menjadi 34,8 pada tahun 2014/2015. Sebaliknya, terjadi penurunan persentase anak usia $7-14$ tahun dengan ibu bekerja. Pada tahun 2007/2008 persentase ibu bekerja sebesar 49,5 persen dan menurun menjadi 45,5 persen pada tahun 2014/2015. Selain itu, terjadi peningkatan keluarga dengan sanitasi layak dari tahun 2007/2008 ke 2014/2015. Persentase keluarga dengan sanitasi layak sebesar 64,2 persen pada tahun 2007/2008 dan meningkat menjadi 74 persen pada tahun 2014/2015.

Penelitian ini menemukan terjadi peningkatan persentase depresi maternal dari tahun 2007/2008 ke 2014/2015 yang ditunjukkan pada Tabel 1. Menurut data persentase IFLS-4 sebesar 7,8 persen ibu dengan anak usia $7-14$ tahun mengalami depresi. Angka ini menjadi 22,5 persen pada IFLS-5. Sebaliknya, terjadi penurunan rata-rata fungsi kognisi dari tahun 2007/2008 ke 2014/2015. Rata-rata kognisi yang dilihat menggunakan Z-score anak umur 7 - 14 tahun adalah 0,25 pada IFLS-4 sedangkan pada IFLS-5 turun menjadi 0,13 . 
Tabel 1. Karakteristik responden

\begin{tabular}{|c|c|c|c|c|}
\hline \multirow{2}{*}{ Karakteristik } & \multicolumn{2}{|c|}{ IFLS-4 (2007/2008) } & \multicolumn{2}{|c|}{ IFLS-5 (2014/2015) } \\
\hline & $\mathbf{n}$ & $\%$ / mean (SD) & n & $\%$ / mean (SD) \\
\hline Fungsi kognisi (Z-score) & 4.463 & $0,25(0,99)$ & 4,997 & $0,13(1,00)$ \\
\hline \multicolumn{5}{|l|}{ Gejala Depresi maternal } \\
\hline Tidak & 4,117 & 92,3 & 3,873 & 77,5 \\
\hline Ya & 346 & 7,8 & 1,124 & 22,5 \\
\hline \multicolumn{5}{|l|}{ Tipe daerah } \\
\hline Perdesaan & 2,162 & 48,4 & 2,111 & 42,3 \\
\hline Perkotaan & 2,301 & 51,6 & 2,886 & 57,8 \\
\hline \multicolumn{5}{|l|}{ Usia melahirkan } \\
\hline$<20$ tahun & 479 & 10,7 & 471 & 9,4 \\
\hline 20-35 tahun & 3,432 & 76,9 & 4,054 & 81,1 \\
\hline$>35$ tahun & 552 & 12,4 & 472 & 9,5 \\
\hline \multicolumn{5}{|l|}{ Pendidikan ibu } \\
\hline Rendah & 2,441 & 54,7 & 2,113 & 42,3 \\
\hline Menengah & 840 & 18,8 & 1,144 & 22,9 \\
\hline Tinggi & 1,182 & 26,5 & 1,740 & 34,8 \\
\hline \multicolumn{5}{|l|}{ Status pekerjaan } \\
\hline Tidak bekerja & 2,252 & 50,5 & 2,740 & 54,8 \\
\hline Bekerja & 2,211 & 49,5 & 2,257 & 45,2 \\
\hline \multicolumn{5}{|l|}{ Status ekonomi } \\
\hline Terbawah & 908 & 20,4 & 1,070 & 21,4 \\
\hline Menengah bawah & 900 & 20,2 & 1,039 & 20,8 \\
\hline Menengah & 866 & 19,4 & 985 & 19,7 \\
\hline Menengah atas & 954 & 21,4 & 990 & 19,8 \\
\hline Tearatas & 835 & 18,7 & 913 & 18,3 \\
\hline \multicolumn{5}{|l|}{ Sanitasi } \\
\hline Tidak layak & 1,600 & 35,9 & 1,297 & 26,0 \\
\hline Layak & 2,863 & 64,2 & 3,700 & 74,0 \\
\hline \multicolumn{5}{|l|}{ Tinggi ibu } \\
\hline Normal & 2,537 & 56,9 & 2,986 & 59,8 \\
\hline Pendek & 1,926 & 43,2 & 2,011 & 40,2 \\
\hline Usia anak & 4.463 & $10,3(2,34)$ & 4,997 & $10,3(2,27)$ \\
\hline \multicolumn{5}{|l|}{ Urutan anak } \\
\hline Pertama & 3,211 & 72,0 & 2,091 & 41,9 \\
\hline Kedua & 994 & 22,3 & 1,475 & 29,5 \\
\hline Ketiga atau lebih & 258 & 5,8 & 1,431 & 28,6 \\
\hline \multicolumn{5}{|l|}{ Jenis kelamin anak } \\
\hline Laki-laki & 2,287 & 51,2 & 2,586 & 51,8 \\
\hline Perempuan & 2,176 & 48,8 & 2,411 & 48,3 \\
\hline \multicolumn{5}{|l|}{ Self-rate health (SRH) } \\
\hline Sehat & 4,150 & 93,0 & 4,564 & 91,3 \\
\hline Tidak sehat & 313 & 7,0 & 433 & 8,7 \\
\hline
\end{tabular}

Hasil analisis inferensial pada Tabel 2 menunjukkan bahwa terdapat hasil yang berbeda terkait hubungan depresi maternal dengan fungsi kognisi pada anak usia $7-14$ tahun pada dua titik tahun yang diamati. Berdasarkan data IFLS-4 (2007/2008) terdapat hubungan yang bermakna antara depresi maternal dengan kognisi anak usia 7 - 14 tahun. 
Anak usia 7 - 14 tahun dengan ibu yang mengalami depresi memiliki rata-rata kognisi yang lebih rendah dibanding anak dengan ibu tanpa depresi. Pada IFLS-5 (2014/2015) meskipun rata-rata nilai kognisi anak usia 7 -
14 tahun dengan ibu yang mengalami depresi lebih rendah dibanding anak dengan ibu tanpa depresi namun hubungan ini menjadi tidak bermakna secara statistik.

Tabel 2. Hubungan depresi maternal dan kognisi pada anak

\begin{tabular}{|c|c|c|c|c|c|}
\hline \multirow{2}{*}{\multicolumn{2}{|c|}{ Karakteristik }} & \multicolumn{2}{|c|}{ IFLS-4 } & \multicolumn{2}{|c|}{ IFLS-5 } \\
\hline & & Koefisien (SE) & p-value & Koefisien (SE) & p-value \\
\hline \multicolumn{6}{|c|}{ Gejala Depresi maternal } \\
\hline & Tidak & Referensi & & Referensi & \\
\hline & Ya & $-0.1(0.05)$ & $0.047 *$ & $-0.05(0.03)$ & 0.088 \\
\hline \multicolumn{6}{|l|}{ Tipe daerah } \\
\hline & Perdesaan & $-0.12(0.03)$ & $0.000^{* *}$ & $-0.1(0.03)$ & $0.000^{* *}$ \\
\hline & Perkotaan & & & & \\
\hline \multicolumn{6}{|c|}{ Usia melahirkan } \\
\hline & $<20$ tahun & $-0.03(0.05)$ & 0.481 & $-0.11(0.05)$ & $0.033^{*}$ \\
\hline & 20-35 tahun & Referensi & & Referensi & \\
\hline & $>35$ tahun & $-0.09(0.04)$ & $0.034 *$ & $0.00(0.05)$ & 0.948 \\
\hline \multicolumn{6}{|c|}{ Pendidikan ibu } \\
\hline & Rendah & $-0.33(0.04)$ & $0.000^{* *}$ & $-0.34(0.03)$ & $0.000 * *$ \\
\hline & Menengah & $-0.1(0.04)$ & $0.015^{*}$ & $-0.19(0.04)$ & $0.000 * *$ \\
\hline & Tinggi & Referensi & & Referensi & \\
\hline \multicolumn{6}{|c|}{ Status pekerjaan } \\
\hline & Tidak bekerja & Referensi & & Referensi & \\
\hline & Bekerja & $0.05(0.03)$ & 0.065 & $-0.03(0.03)$ & 0.258 \\
\hline \multicolumn{6}{|c|}{ Status ekonomi } \\
\hline & Terbawah & $-0.14(0.05)$ & $0.002 *$ & $0.02(0.04)$ & 0.656 \\
\hline & Menengah bawah & $-0.11(0.04)$ & $0.009^{*}$ & $0.02(0.04)$ & 0.700 \\
\hline & Menengah & $-0.13(0.04)$ & $0.002 *$ & $0.04(0.04)$ & 0.334 \\
\hline & Menengah atas & $-0.09(0.04)$ & $0.020 *$ & $0.07(0.04)$ & 0.122 \\
\hline & Tearatas & Referensi & & Referensi & \\
\hline \multicolumn{6}{|l|}{ Sanitasi } \\
\hline & Tidak layak & $-0.23(0.03)$ & $0.000^{* *}$ & $-0.12(0.03)$ & $0.000^{* *}$ \\
\hline & Layak & Referensi & & Referensi & \\
\hline \multicolumn{6}{|l|}{ Tinggi ibu } \\
\hline & Normal & Referensi & & Referensi & \\
\hline & Pendek & $-0.03(0.03)$ & 0.222 & $-0.03(0.03)$ & 0.305 \\
\hline Usia anak & & $0.17(0.01)$ & $0.000^{* *}$ & $0.16(0.01)$ & $0.000^{* *}$ \\
\hline \multicolumn{6}{|l|}{ Urutan anak } \\
\hline & Pertama & Referensi & & Referensi & \\
\hline & Kedua & $0.03(0.03)$ & 0.466 & $-0.03(0.03)$ & 0.337 \\
\hline & Ketiga atau lebih & $0.06(0.07)$ & 0.350 & $-0.09(0.04)$ & 0.010 \\
\hline \multicolumn{6}{|c|}{ Jenis kelamin anak } \\
\hline & Laki-laki & $0.01(0.03)$ & 0.846 & $-0.02(0.03)$ & 0.460 \\
\hline & Perempuan & Referensi & & Referensi & \\
\hline \multicolumn{6}{|l|}{ SRH } \\
\hline & Sehat & Referensi & & Referensi & \\
\hline & Tidak sehat & $0.02(0.06)$ & 0.711 & $-0.07(0.05)$ & 0.159 \\
\hline
\end{tabular}




\section{PEMBAHASAN}

Penelitian ini bertujuan untuk melihat apakah terdapat perbedaan hubungan depresi maternal dan fungsi kognisi anak usia 7 - 14 tahun pada dua titik tahun. Pada tahun 2007/2008 terdapat hubungan yang bermakna antara depresi maternal dan nilai kognisi anak usia $7-14$ tahun. Anak dengan ibu yang mengalami depresi cenderung memiliki nilai kognisi yang lebih rendah dibanding anak dengan ibu tanpa depresi setelah dikontrol menggunakan beberapa variabel confounding. Temuan ini sejalan dengan beberapa penelitian lain sebelumnya. Penelitian kohor di Perancis menemukan bahwa depresi maternal yang persisten memiliki efek negatif terhadap kognisi anak yang diukur menggunakan nilai Intelligence Quotient $(I Q) .{ }^{14}$ Selain itu penelitian kohor lainnya di Inggris juga menemukan hal serupa. Anak dari ibu dengan depresi maternal memiliki risiko mengalami perkembangan fungsi eksekutif yang lebih buruk dibanding anak dengan ibu tanpa depresi. Istilah fungsi eksekutif anak mengacu pada proses kemampuan anak yang lebih sulit seperti pengendalian diri, kognisi, serta kemampuan mengingat. ${ }^{27} \mathrm{Hal}$ ini dapat disebabkan karena ibu yang mengalami depresi cenderung kurang sensitif dan lebih emosional saat berinteraksi dengan anak dibanding ibu tanpa gejala depresi. Hal ini akan berpengaruh terhadap pengasuhan ibu terhadap anaknya. Selain itu, ibu juga membantu interaksi anak dengan lingkungan dan membantu anak menjalani pengalaman mereka dengan dunia luar. Ibu juga mengajarkan kepekaan dan daya tanggap terhadap apa yang terjadi di lingkungan. Interaksi dan keterikatan secara emosional antara ibu dan anak akan berpengaruh terhadap kemampuan kognisi dan kemampuan sosialemosional anak. Depresi maternal meningkatkan kemungkinan perilaku pengasuhan negatif seperti ketidaksabaran, sensitivitas rendah, kurangnya kepedulian, serta permusuhan dan pada akhirnya akan berdampak negatif terhadap kemampuan kognisi anak. ${ }^{3}$

Namun penelitian ini menemukan hal yang berbeda pada tahun 2014/2015. Berdasarkan data IFLS-5 depresi maternal dan fungsi kognisi anak usia 7 - 14 tahun memberikan arah hubungan yang sama dengan IFLS-4, namun hubungan ini tidak bermakna. Beberapa penelitian sebelumnya juga menemukan hal yang serupa. Penelitian kohor di Perancis menemukan bahwa tidak terdapat pengaruh yang bermakna baik kecemasan maupun depresi pada ibu terhadap kognisi anak. ${ }^{15}$ Selain itu penelitian di Inggris juga menemukan hal yang serupa bahwa depresi maternal tidak berpengaruh terhadap perkembangan motorik, perilaku, serta kognisi pada anak. ${ }^{16}$ Hasil ini mungkin karena adanya tidak cukupnya kekuatan untuk mendeteksi hubungan antara depresi maternal dengan fungsi kognisi anak pada tahun tersebut. Selain itu, hal ini dapat disebabkan adanya mediator lain yang tidak dipantau dalam penelitian ini. Sebuah studi di London Selatan yang melihat hubungan depresi postnatal dengan kecerdasan intelektual anak setelahnya ketika berusia 11 tahun menemukan bahwa depresi postnatal ibu dapat memprediksi IQ anak setelah 10 tahun kemudian. Akan tetapi, keadaan kesehatan mental ibu ketika anak berusia 11 tahun tidak berhubungan dengan kemampuan akademik anak setelah dikontrol dengan IQ ibu. Parenteal Intelligence Quotient (IQ orang tua) merupakan salah satu faktor yang penting dalam menganalisis hubungan ini akan tetapi dalam studi ini tidak turut dianalisis. ${ }^{28}$

Penelitian sebelumnya menyarankan bahwa terdapat efek psikologis ibu pada seribu hari pertama kehidupan (kehamilan sampai dengan dua tahun pertama anak) lebih berpengaruh terhadap perkembangan kognisi anak dibanding kesehatan mental ibu setelah anak melewati dua tahun pertama. Perkembangan otak meningkat pesat pada seribu hari pertama kehidupan dan sudah mulai melandai setelah anak berusia dua tahun. ${ }^{29}$ Hal ini menyebabkan lemahnya hubungan antara depresi maternal dengan fungsi kognisi anak usia 7 - 14 tahun yang diukur secara cross-sectional.

Adanya perbedaan temuan antara dua titik tahun juga dapat disebabkan adanya pergeseran pola asuh. Peran ibu sebagai pengasuh utama anak pada era modern bergeser digantikan orang lain seperti ayah, kakek, nenek, atau kerabat lainnya. Kehidupan keluarga yang berubah dari masa ke masa menyebabkan berubahnya peran ibu dalam rumah tangga. Beberapa penelitian sebelumnya mengaitkan hal ini dengan pengasuhan informal dan pengasuhan formal. Pengasuhan informal termasuk pengasuhan oleh ibu dan keluarga lainnya seperti kakek, nenek, atau kerabat lainnya. Sedangkan pengasuhan formal adalah 
pengasuhan yang lebih diatur seperti daycare, pendidikan anak usia dini (PAUD) ataupun sekolah. Pengasuhan formal sering dianggap memiliki kualitas yang lebih baik dibanding pengasuhan informal dalam mendukung perkembangan kognisi anak. ${ }^{30-32}$ Badan Pusat Statistik mencatat kenaikan persentase anak yang mengikuti PAUD di Indonesia. Persentase anak yang mengikuti PAUD pada tahun 2009 sebesar 13,1 persen dan naik menjadi 28,3 pada tahun $2018 .{ }^{33,34}$ Hal ini menyebabkan hubungan antara kesehatan mental ibu termasuk depresi maternal dan fungsi kognisi anak semakin menurun seiring berjalannya waktu.

\section{KESIMPULAN}

Penelitian ini menemukan hal yang berbeda terkait hubungan depresi maternal dan fungsi kognisi anak usia 7 - 14 tahun. Pada tahun 2007/2008 depresi maternal memiliki hubungan yang bermakna dengan fungsi kognisi anak usia $7-14$ tahun. Pada tahun 2014/2015 meskipun memberikan arah hubungan yang sama dengan penelitian sebelumnya, namun hubungan ini menjadi tidak bermakna. Meskipun demikian jika dilihat dari dua sumber data tersebut, terdapat peningkatan proporsi depresi maternal. Hal ini juga patut menjadi perhatian khusus.

\section{SARAN}

Skrining terhadap depresi maternal dan pengobatan pada ibu yang terdiagnosis depresi menjadi upaya untuk menciptakan pengasuhan yang responsif. Selain itu, penelitian tambahan juga harus dilakukan untuk memberikan bukti kausalitas hubungan ini. Misalnya melalui penilaian efektivitas intervensi pada kesehatan mental ibu yang berdampak terhadap peningkatan fungsi kognisi anak.

\section{PERSETUJUAN ETIK}

IFLS telah mendapatkan persetujuan etik dari komisi etik RAND di Amerika Serikat dan Universitas Gajah Mada (UGM) di Indonesia. Data IFLS dapat diakses melalui http://www.rand.org/labor/FLS/IFLS.htm./IFL S.

\section{UCAPAN TERIMA KASIH}

Penulis mengucapkan terimakasih kepada Dr.dr. Sri Idaiani, Sp.KJ; Dr.dr. Teti Tejayanti, MKM; dan dr. Lina R Mangaweang, Sp.KJ yang telah memberikan masukan secara substansi. Terimakasih kami ucapkan juga kepada Dina Rizkiani, ST, M.E.K.K dan M. Fajar Rakhmadi, SE, ME atas masukannya dalam hal analisis.

\section{DAFTAR PUSTAKA}

1. Patton GC, Sawyer SM, Santelli JS, Ross DA, Afifi R, Allen NB, et al. Our future: a Lancet commission on adolescent health and wellbeing. Lancet. 2016;387(10036):2423-78.

2. Golden AL. Association between child poverty and academic achievement. JAMA Pediatr. 2016;170(2):178-9.

3. Liu Y, Kaaya S, Chai J, McCoy DC, Surkan PJ, Black MM, et al. Maternal depressive symptoms and early childhood cognitive development: a meta-analysis. Psychol Med. 2017;47(4):680-9.

4. Marmot M. The health gap: the challenge of an unequal world. Lancet. 2015;386(10011):2442-4.

5. BPS. Keadaan Angkatan Kerja di Indonesia. Jakarta; 2018.

6. BPS. Analisis Perkembangan Statistik Ketenagakerjaan (Laporan Sosial Indonesia 2007). Jakarta; 2007.

7. BPS. Keadaan Angkatan Kerja ci Indonesia. Jakarta; 2014.

8. BPS. Keadaan Angkatan Kerja di Indonesia. Jakarta; 2019.

9. Kuehner C. Why is depression more common among women than among men? The Lancet Psychiatry. 2017;4(2):146-58.

10. Ghaedrahmati M, Kazemi A, Kheirabadi G, Ebrahimi A, Bahrami M. Postpartum depression risk factors: A narrative review. J Educ Health Promot. 2017;6.

11. Righetti-Veltema $\mathrm{M}$, Bousquet $\mathrm{A}$, Manzano J. Impact of postpartum depressive symptoms on mother and her 18-month-old infant. Eur Child Adolesc Psychiatry. 2003 Apr 1;12(2):75-83.

12. Drury SS, Scaramella L, Zeanah CH. The neurobiological impact of 
postpartum maternal depression: prevention and intervention approaches. Child Adolesc Psychiatr Clin. 2016;25(2):179-200.

13. Koutra K, Roumeliotaki T, Kyriklaki A, Kampouri M, Sarri K, Vassilaki M, et al. Maternal depression and personality traits in association with child neuropsychological and behavioral development in preschool years: Mother-child cohort (Rhea Study) in Crete, Greece. J Affect Disord. 2017;217:89-98.

14. Van Der Waerden J, Bernard JY, De Agostini M, Saurel-Cubizolles M, Peyre $\mathrm{H}$, Heude B, et al. Persistent maternal depressive symptoms trajectories influence children's IQ: The EDEN mother-child cohort. Depress Anxiety. 2017;34(2):105-17.

15. Ibanez G, Bernard JY, Rondet C, Peyre $\mathrm{H}$, Forhan A, Kaminski M, et al. Effects of antenatal maternal depression and anxiety on children's early cognitive development: a prospective cohort study. PLoS One. 2015;10(8):e0135849.

16. Hanley GE, Brain U, Oberlander TF. Infant developmental outcomes following prenatal exposure to antidepressants, and maternal depressed mood and positive affect. Early Hum Dev. 2013;89(8):519-24.

17. Strauss J, Witoelar F, Sikoki B. The fifth wave of the Indonesia family life survey: overview and field report. RAND St Monica, CA, USA. 2016;

18. Abdelkarim O, Ammar A, Chtourou H, Wagner M, Knisel E, Hökelmann A, et al. Relationship between motor and cognitive learning abilities among primary school-aged children. Alexandria J Med. 2017;53(4):325-31.

19. Maika A, Mittinty MN, Brinkman S, Lynch J. Associations of Early-and Later-Childhood Poverty With Child Cognitive Function in Indonesia: Effect decomposition in the presence of exposure-induced mediator-outcome confounding. Am J Epidemiol. 2017;185(10):879-87.
20. Andresen EM, Malmgren JA, Carter WB, Patrick DL. Screening for depression in well older adults: Evaluation of a short form of the CESD. Am J Prev Med. 1994;10(2):77-84.

21. Mohebbi M, Nguyen V, McNeil JJ, Woods RL, Nelson MR, Shah RC, et al. Psychometric properties of a short form of the Center for Epidemiologic Studies Depression (CES-D-10) scale for screening depressive symptoms in healthy community dwelling older adults. Gen Hosp Psychiatry. 2018;51:118-25.

22. Radloff LS. The CES-D scale: A selfreport depression scale for research in the general population. Appl Psychol Meas. 1977;1(3):385-401.

23. Sclar GD, Garn J V, Penakalapati G, Alexander KT, Krauss J, Freeman MC, et al. Effects of sanitation on cognitive development and school absence: a systematic review. Int J Hyg Environ Health. 2017;220(6):917-27.

24. Watanabe K, Petri Jr WA. Environmental enteropathy: elusive but significant subclinical abnormalities in developing countries. EBioMedicine. 2016;10:25-32.

25. Pinkerton $\mathrm{R}$, Oriá RB, Lima AAM, Rogawski ET, Oriá MOB, Patrick PD, et al. Early childhood diarrhea predicts cognitive delays in later childhood independently of malnutrition. Am J Trop Med Hyg. 2016;95(5):1004-10.

26. Maika A, Mittinty MN, Brinkman S, Harper S, Satriawan E, Lynch JW. Changes in Socioeconomic Inequality in Indonesian Children's Cognitive Function from 2000 to 2007: A Decomposition Analysis. PLoS One. 2013 Oct;8(10):e78809.

27. Hughes C, Roman G, Hart MJ, Ensor R. Does maternal depression predict young children's executive function?-a 4-year longitudinal study. J Child Psychol Psychiatry. 2013;54(2):169-77.

28. Hay DF, Pawlby S, Sharp D, Asten P, Mills A, Kumar R. Intellectual problems shown by 11-year-old children whose mothers had postnatal depression. J 
child Psychol psychiatry. 2001;42(7):871-89.

29. Behrman JR. Growth faltering in the first thousand days after conception and catch-up growth. Oxford Handb Econ Hum Biol. 2015;

30. Paquin C, Côté SM, Tremblay RE, Séguin JR, Boivin M, Herba CM. Maternal depressive symptoms and children's cognitive development: Does early childcare and child's sex matter? PLoS One. 2020;15(1):e0227179.

31. Rigby E, Ryan RM, Brooks-Gunn J. Child care quality in different state policy contexts. J Policy Anal Manag J Assoc Public Policy Anal Manag.
2007;26(4):887-908.

32. Charrois J, Côté SM, Paquin S, Séguin JR, Japel C, Vitaro F, et al. Maternal depression in early childhood and child emotional and behavioral outcomes at school age: examining the roles of preschool childcare quality and current maternal depression symptomatology. Eur Child Adolesc Psychiatry. 2019;112.

33. Badan Pusat Statistik. Statistik Pendidikan 2009. Jakarta; 2009.

34. Badan Pusat Statistik. Statistik Pendidikan Indonesia 2018. Jakarta; 2018. 